\title{
Fulminant bilateral Haemophilus influenzae keratitis in a patient with hypovitaminosis $A$ treated with contaminated autologous serum
}

This article was published in the following Dove Press journal:

Clinical Ophthalmology

I 2 January 201 I

Number of times this article has been viewed

Empar Sanz-Marco'

Maria J Lopez-Prats'

Salvador Garcia-Delpech ${ }^{1,4}$

Patricia Udaondo'

Manuel Diaz-Llopis ${ }^{1-3}$

'Ophthalmology, La Fe University

Hospital of Valencia, Valencia, Spain;

${ }^{2}$ Faculty of Medicine, University of

Valencia, Valencia, Spain; ${ }^{3}$ Biomedical

Research Center for Rare Diseases

Network (CIBERER), Valencia,

Spain; ${ }^{4}$ Faculty of Medicine, Catholic

University of Valencia, Valencia, Spain

Correspondence: Empar Sanz-Marco

2I Campanar Av. Valencia, Spain

Tel +346652645I8

Emailempar19@hotmail.com
Abstract: We report on a patient with hypovitaminosis A treated with autologous serum (AS) who had bilateral infectious ulcers positive for Haemophilus influenzae. The patient suffered a perforation of his right eye and total healing of his left eye with a residual leukoma. In cases of severe malnutrition, serum levels of vitamins and bacteriostatic and growth factors are reduced, so AS would not only be ineffective but also increase the risk of secondary corneal infection. The prophylactic use of a topical antibiotic would be useful in treatment with AS, especially in patients who do not use and adequately store the eye drops, as in our patient.

Keywords: Haemophilus influenzae, hypovitaminosis A, bilateral infectious ulcers

Haemophilus influenzae is an uncommon corneal pathogen that generally affects corneas with risk factors; ${ }^{1}$ it accounts for $<2 \%$ of all corneal ulcers ${ }^{2}$. H. influenzae is a Gram-negative coccobacillus that infects humans. In ophthalmology, H. influenzae has been reported as a cause of endophthalmitis, ${ }^{3}$ cellulitis, acute bacterial conjunctivitis in children, ${ }^{4}$ and keratitis and scleritis. ${ }^{5}$

Autologous serum (AS) has been proven effective and safe in the management of ocular surface disorders ${ }^{6,7}$ such as Sjögren's syndrome ${ }^{8}{ }^{8}$ persistent epithelial defects, ${ }^{9}$ keratoconjunctivitis sicca, and vitamin A deficiency. ${ }^{10}$

We report the first bilateral case of corneal ulcers infected by $H$. influenzae due to the use of contaminated AS in severe hypovitaminosis A.

Hypovitaminosis A must be suspected in cases of severe dry eye in malnourished or alcoholic patients. Although the standard treatment is vitamin supplements, AS has been shown to be beneficial. ${ }^{10}$

\section{Case report}

A 38-year-old man with chronic alcoholism and cachexia presented with long-lasting watering and burning of the eyes. His corrected visual acuity was 20/20 and he exhibited conjunctival keratinization, reduced tear break-up time, moderate superficial keratitis punctata, and Schirmer below $5 \mathrm{~mm}$ (Figure 1). Blood levels of vitamin E were reduced $(4.3 \mathrm{mg} / \mathrm{L})$, and those of retinol were undetectable.

After the poor outcomes obtained using treatment with artificial tears and oral vitamin A (10,000 IU per day), 20\% AS 10 times a day was added.

The protocol followed for AS preparation was as follows: $30 \mathrm{~mL}$ of the patient's blood was left to clot at $4^{\circ} \mathrm{C}$ for $10-12$ hours before centrifuging at $4500 \mathrm{rpm}$ for 15 minutes. The serum was separated in a laminar flow cabinet, diluted with sterile 
A

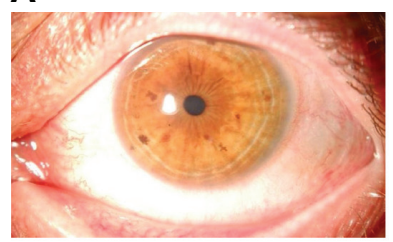

C

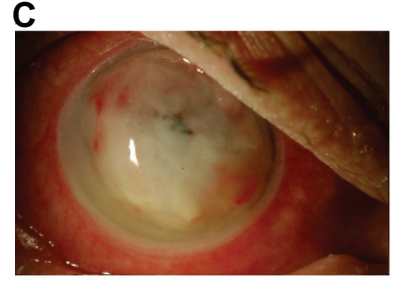

E

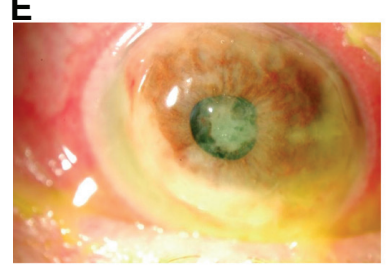

G

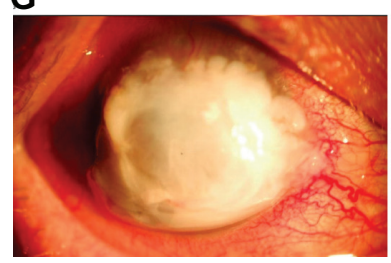

B

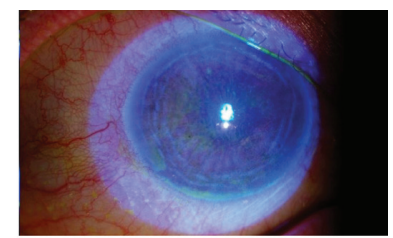

D

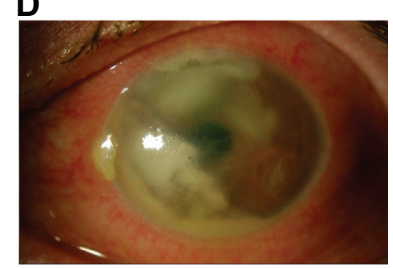

$\mathbf{F}$

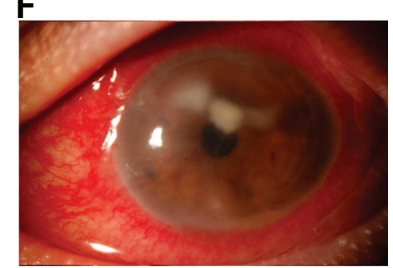

H

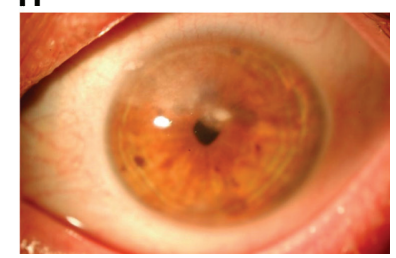

Figure I A) and B) Conjunctival keratinization and moderate superficial keratitis punctata. C) Infectious ulcers with total hipopion. D) Infectious ulcers with $2 \mathrm{~mm}$ hypopion. E) Perforation with drainage of purulent content. F) Improvement of infectious keratitis. G) Residual leukoma and disappearance of ocular xerophthalmia. H) Coating with amniotic membrane.

saline $(0.9 \%)$ to a $20 \%$ concentration, and aliquoted in $3.0 \mathrm{~mL}$ portions clearly labeled with the patient's details. The vials should have been kept frozen at $-20^{\circ} \mathrm{C}$ and a fresh bottle thawed, stored at $4^{\circ} \mathrm{C}$, and used for treatment every week.

After 20 days of treatment, the patient complained of loss of bilateral vision. Bilateral infectious ulcers with total hypopion were seen in the oculus dexter (right eye [OD]) and infectious ulcers with $2 \mathrm{~mm}$ hypopyon in the oculus sinister (left eye [OS]) (Figure 1). The patient admitted not storing the eye drops at $4^{\circ} \mathrm{C}$.

Treatment with topical $3.5 \%$ vancomycin, $5 \%$ ceftazidime, and oral linezolid $600 \mathrm{mg}$ every 12 hours was started. Fortyeight hours later, the patient had right perforation with drainage of purulent content and improvement in his OS (Figure 1). The antibiotic schedule was maintained, and urgent coating was performed on the amniotic membrane.

Cultures of corneal scraping and AS were positive for H. influenzae susceptible to ceftazidime and Staphylococcus epidermidis susceptible to vancomycin.

The biochemical analysis of AS resulted in undetectable vitamin $\mathrm{E}$ and retinol levels. Immunoglobulin and lysozyme serum levels were also undetectable. AS was discontinued, and oral vitamin supplements were increased $(50,000 \mathrm{IU}$ per day).

Three weeks later, vitamin A and E serum levels were restored; the patient had corrected visual acuity of 16/20 in the OS, with residual leukoma not involving the visual axis; disappearance of ocular xerophthalmia; and corrected visual acuity of the OD for light perception, with good coating of the amniotic membrane (Figure 1).

\section{Discussion}

AS has been shown to be effective in the management of xerophthalmia ${ }^{10}$ and other ocular surface disorders. ${ }^{6-9}$ Its main advantage is the large amount of nutrients, growth factors, and vitamins it contains. ${ }^{7}$ Its vitamin A levels $(46 \mathrm{mg} / \mathrm{mL})$ are higher than the levels of umbilical cord serum $(0.23 \mathrm{mg} / \mathrm{mL})$ and natural $(0.02 \mathrm{mg} / \mathrm{mL})$ and artificial tears, ${ }^{7}$ so AS may be useful in vitamin A deficiency. ${ }^{10}$

However, if serum nutrient levels are low, AS will have the same deficiency; in this case we should evaluate its effectiveness and the need for coadjuvant treatments, or consider the possibility of using blood from a donor.

AS drops have a high protein content, so there is a significant risk of microbial colonization. Nevertheless, toxicity of any added preservatives can negate some of the beneficial effects of AS. AS seems to be a safe treatment; it does not require preservatives, as it contains bacteriostatic factors (immunoglobulins and lysozyme) and has a low risk of contamination, provided that preparation and storage protocols are followed. ${ }^{11}$

No severe infections secondary to contaminated AS have been reported in previous studies, but indolent infectious keratitis has been described. Tananuvat et al studied 15 eyes treated with AS and described three infectious ulcers: one coagulase-negative Staphylococcus corneal ulcer, one stitch abscess without identified organism, and one Candida infectious crystalline keratopathy, although the persistent epithelial defect had healed. ${ }^{12}$ Lagnado et al cultured 134 AS samples; 13 samples from six patients were positive for $S$. epidermidis, Micrococcus, S. viridans, and S. aureus, all of them without clinical repercussion. ${ }^{11}$

However, in a malnourished subject, serum levels of immunoglobulins will be reduced, ${ }^{13}$ as in our patient, therefore increasing the probability for secondary corneal infection.

Furthermore, H. influenzae is an opportunistic pathogen with demanding nutritional requirements. It requires factor 
$\mathrm{X}$ and factor $\mathrm{V}$ for growth under aerobic conditions. ${ }^{14}$ Serum has no factor I, V, VIII, or XIII. H. influenzae would not grow in serum for lack of factor $\mathrm{V}$, but should it be colonized by $S$. epidermidis, as in our case, this would act as a donor of factor $\mathrm{V}$, and $H$. influenzae would grow.

We do not know whether the contamination was due to the preparation of the AS or due to inadequate storage of the AS by the patient, because the culture was from only one AS bottle, the last of the three obtained in the first and only blood extraction for AS.

In conclusion, the outcome of this patient suggests two major issues. First, if the patient does not adequately use and store eye drops, the risk of infection will increase, with the appearance of severely infectious keratitis. Therefore, the prophylactic use of an antibiotic would be useful. Second, in the case of severe malnutrition, serum levels of vitamins and bacteriostatic and growth factors would be reduced, so AS would not only be ineffective but also increase the risk of secondary corneal infection.

\section{Disclosure}

No authors have any financial/conflicting interests to disclose.

\section{References}

1. Yang KS, Lin HC, Ma DH, et al. Ulcerative keratitis caused by Haemophilus influenzae. Cornea. 2006;25(6):701-704.

2. Asbell P, Stenson S. Ulcerative keratitis: survey of 30 years' laboratory experience. Arch Ophthalmol. 1982;100(1):77-80.
3. Yoder DM, Scott IU, Flynn HW Jr, Miller D. Endophtalmitis caused by Haemophilus Influenzae. Ophtalmology. 2004;111(11):2023-2026.

4. Soukiasian SH, Baum J. Bacterial conjunctivitis. In: Krachmer JH, Mannis MJ, Holland EJ, editors. Cornea. St. Louis, MO: Mosby;1997: 759-771.

5. Sykes SO, Riemann C, Santos CI, et al. Haemophilus influenzae associated scleritis. Br J Ophthalmol. 1999;83(4):410-413.

6. Tsubota K, Higuchi A. Serum application for the treatment of ocular surface disorders. Int Ophthalmol Clin. 2000(4);113-122.

7. Geerling G, Maclennan, Hartwig D. Autologous serum eye drops for ocular surface disorders. Br J Ophthalmol. 2004;88(11):1467-1474.

8. Tsubota K, Goto E, Fujita H, et al. Treatment of dry eye by autologous serum application in Sjögren's Syndrome. Br J Ophthalmol. 1999;83(4): 390-395.

9. Tsubota K, Goto E, Shimmura S, Shimazaki J. Treatment of persistent corneal epithelial defect by autologous serum application. Ophthalmology. 1999;106(10):1984-1989.

10. Bosch-Valero J, Martín-Aviá J, Sierra-Barreras J, et al. Use of autologous serum in hypovitaminosis-induced ocular pathology. Arch Soc Esp Oftalmol. 2008;83(1):45-48.

11. Lagnado R, King AJ, Donald F, Dua HS. A protocol for low contamination risk of autologous serum drops in the management of ocular surface disorders. Br J Ophthalmol. 2004;88(4):464-465.

12. Tananuvat N, Daniell M, Sullivan LJ, et al. Controlled study of the use of autologous serum in dry eye patients. Cornea. 2001;20(8):802-806.

13. Amaral JF, Foschetti DA, Assis FA, Menezes JS, Vaz NM, Faria AM. Immunoglobulin production is impaired in protein-deprived mice and can be restored by dietary protein supplementation. BrazJ Med Biol Res. 2006;39(12):1581-1586.

14. Cartwright CP, Stock F, Gill VJ. Improved enrichment broth for cultivation of fastidious organisms. J Clin Microbiol. 1994;32(7):1825-1826.
Clinical Ophthalmology

\section{Publish your work in this journal}

Clinical Ophthalmology is an international, peer-reviewed journal covering all subspecialties within ophthalmology. Key topics include: Optometry; Visual science; Pharmacology and drug therapy in eye diseases; Basic Sciences; Primary and Secondary eye care; Patient Safety and Quality of Care Improvements. This journal is indexed on PubMed

Submit your manuscript here: http://www.dovepress.com/clinical-ophthalmology-journal

\section{Dovepress}

Central and CAS, and is the official journal of The Society of Clinical Ophthalmology (SCO). The manuscript management system is completely online and includes a very quick and fair peer-review system, which is all easy to use. Visit http://www.dovepress.com/testimonials. php to read real quotes from published authors. 